\title{
STRUCTURE OF THE BARENTS SEA FROM SEISMIC REFRACTION*
}

\author{
V. RENARD \\ Centre Océanologique de Bretagne, Brest (France) \\ and \\ J. MALOD \\ Laboratoire de Géologie Marine, Faculté des Sciences, Rennes (France)
}

Received August 3, 1974

Revised version received September 9, 1974

\begin{abstract}
- The Barents Sea is underlain by a thick (up to $5 \mathrm{~km}$ ) sedimentary basin. Seismic refraction has outlined four main velocity discontinuities which have been correlated with geological units on the basis of the geological history of the region. The basin is underlain by a crystalline basement, the nature of which cannot be determined on the basis of seismic velocity alone. Metamorphosed Paleozoic units (velocities around $5-4 \mathrm{~km} / \mathrm{sec}$ ) lie over this basement. Their thickness is not well established but appears to reach 1 or $2 \mathrm{~km}$ in some cases. A very distinct and thick (up to $2.5 \mathrm{~km}$ ) layer $(4.1 \mathrm{~km} / \mathrm{sec})$ is found almost everywhere and is thought to correspond to a major discontinuity at the end ot the Paleozoic. This discontinuity is followed by a variable velocity layer $(2.4-4 \mathrm{~km} / \mathrm{sec}$, up to $1.2 \mathrm{~km}$ thick) which includes Mesozoic and Cenozoic sediments and is limited to the south of the Barents Sea. The absence of thick Tertiary deposits support the idea that the Barents shelf was emergent at that time. Recent low-velocity sediments are found close to the shelf edge. -

Gravity anomaly trends reflect a series of depressions of the $5.4-\mathrm{km} / \mathrm{sec}$ layer isobath map and suggest that the deeper part of the basin is made of a succession of faulted blocks or intense folds.
\end{abstract}

\section{Introduction}

In 1970, R.V. "Jean Charcot" made a reconnaissance geophysical survey of the Norwegian continental margin including the Barents Sea. Continuous seismic, magnetic and gravity measurements were recorded (Fig. 1). In the Barents Sea, 45 sonobuoys were launched in order to outline the deep structure of the area. Results of this refraction work are presented in this paper.

The survey extends from $70^{\circ}$ to $77^{\circ} \mathrm{N}$ latitude and $10^{\circ}$ to $35^{\circ} \mathrm{E}$ longitude and covers broadly the western part of the Barents Sea including the transition to the Norwegian Sea.

\section{Morphology}

Fig. 1 is a compilation of bathymetric data from our survey and previous sources [1]. It outlines the main

\footnotetext{
* Contribution no. 274 of the Département Scientifique, Centre Océanologique de Bretagne.
}

morphological units of this epicontinental sea. The Barents Sea valley or trough, with an east-northeastwest-southwest trend displays several depressions over $500 \mathrm{~m}$ deep. North of $74^{\circ}$ latitude the valley changes into a northeast-southwest direction and shallows up progressively. Barents Sea trough narrows and gets shallower towards the edge of the shelf. Centered around this narrow exutory is an important delta suggesting that drainage from the Barents Sea has been important.

Spitsbergen Bank, north of the Barents Valley, averages $100 \mathrm{~m}$ in depth. Its southeastern limit with the Barents Valley is outlined by a slope of the order of $1 \%$, which is markedly higher than that of other areas of the Barents Sea. Spitsbergen Bank is almost horizontal with little relief except for Hopen and Bear Islands. To the north, it is separated from Spitsbergen by Storfjord.

South of the Barents Valley lies a series of rises such as North Cape Bank and Mourmansk Rise, and closed depressions 50-100 m deep. 


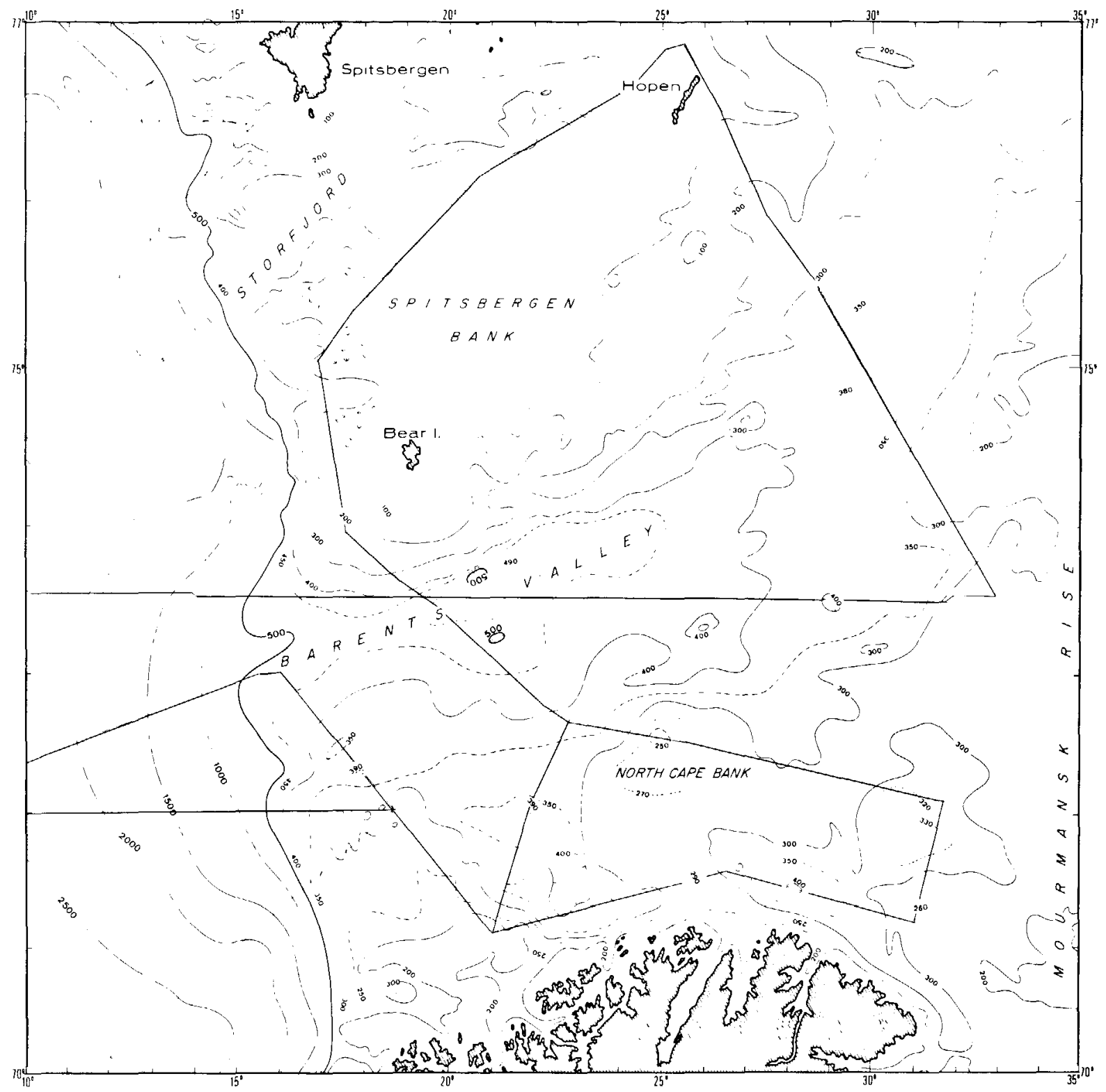

Fig. 1. Bathymetric map of the Barents Sea area based on Eggvin [1], "Jean Charcot" cruise and French Navy Hydrographic Service data. Contour interval is $500 \mathrm{~m}$ below $500 \mathrm{~m}$ and $100 \mathrm{~m}$ above. Closer contour interval is used to underline depressions. Track line of R.V. "Jean Charcot" cruise is indicated.

Ice caps have covered Norway and Spitsbergen during Quaternary glaciations. The areal extent of these caps over the Barents Sea is, however, questionable. According to Lliboutry [2], Schytt et al. [3] and Hoppe [4], a thick ice sheet covered the northern Barents Sea but probably not the Barents Valley. The latter one was more likely covered with floating sea ice. Melting of this ice cap may by isostatic adjustment have created the escarpment limiting Spitsbergen Bank to the south.

Erosion in the Barents Valley can be due to a drainage under floating sea ice towards the west of 


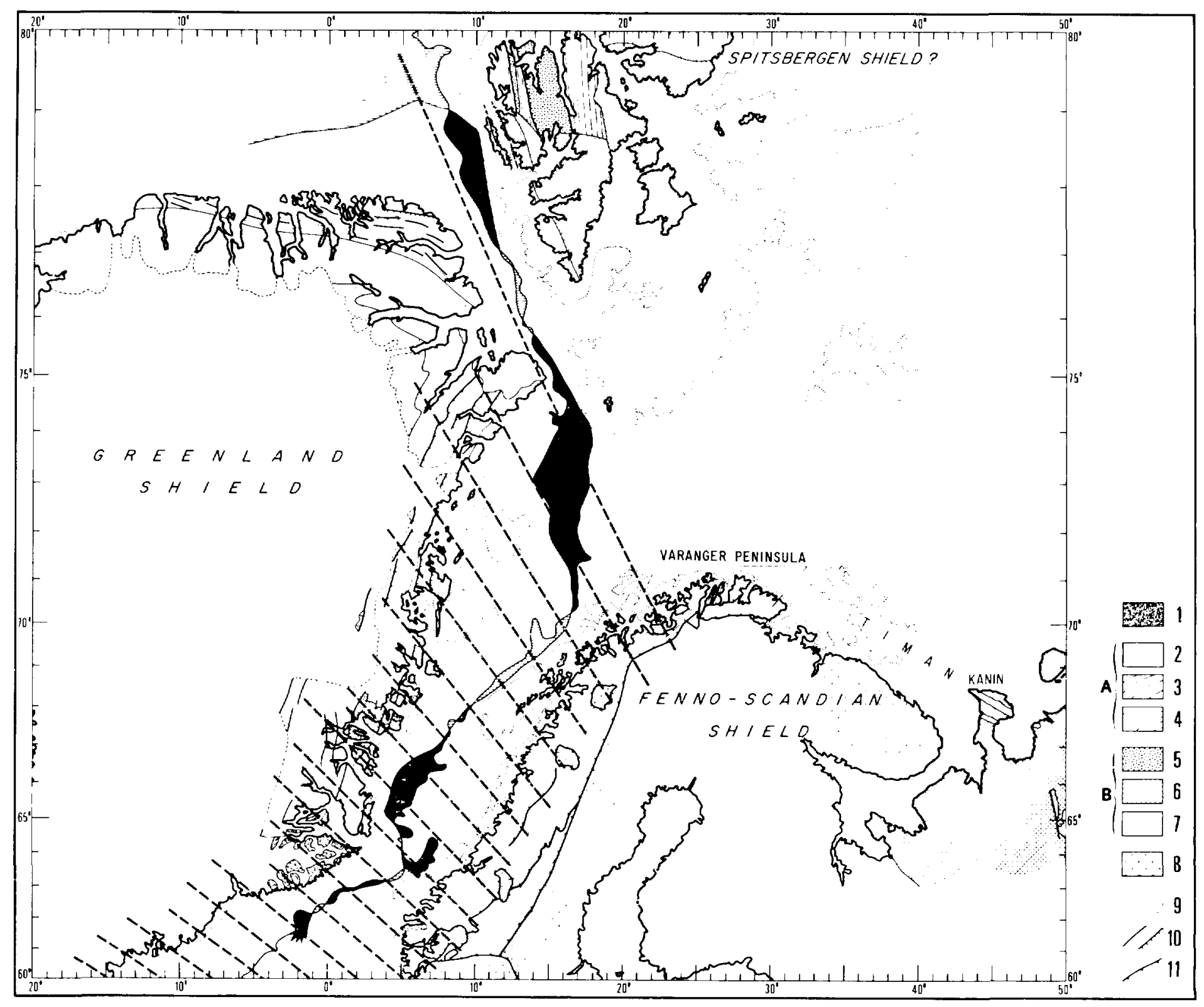

Fig. 2. Norwegian Sea pre-opening reconstruction of continents with rotation pole of Le Pichon and Francheteau (personal communication). Main geological units are reported; 1 = East Greenland intrusives; 2 = Timan Riphean chain; $3=$ Caledonides of Norway and East Greenland; $4=$ northeast Greenland Caledonides; $5=$ Devonian Old Red Sandstones from Spitsbergen; $6=$ post-orogenic platform; $7=$ Caledonian chain autochthonous units; $8=$ Precambrian shield; $9=$ ice limit; $10=$ faults; 11 = thrusts. Black indicates zone of overlap, horizontal lines denote the zone of underlap in reconstruction. 
water mass derived from Spitsbergen and Fennoscandian ice caps. This drainage could explain the series of sinks in the bottom reliefs.

\section{Geological framework}

The Barents Sea is an epicontinental sea that lies over Precambrian shields and converging fold belts. The relative position of these belts is illustrated in a reconstruction of Greenland and Norway before the opening of the Norwegian Sea (Fig. 2).

Three main shields form the structural basement of this area; the Greenland shield to the west, the Fennoscandian shield to the south and the Spitsbergen shield to the north. The existence of the last shield has been proposed by Sokolov et al. [5] and it extends from Spitsbergen to Franz Joseph Land. Its existence is, however, not well established.

Between these shields, two main orogenic belts have been emplaced: the northwest-trending Cambrian belt of Timan found in Kanin and Varanger peninsulas [6] and the Silurian Caledonides belt between Norway and Greenland. Rocks of the Timan belt have been correlated with East Greenland (Eleonor Bay) and Spitsbergen (Heckla Hoeck) formations [7]. This correlation may indicate a possible prolongation of Timan belt across the Barents Sea. Relationships between northeast-trending Greenland and Norwegian and north-trending Spitsbergen Caledonides are not clear and these belts cannot be easily correlated across the Barents Sea.

Post-orogenic movements have developed additional structures. In Devonian times north-south grabens were created in Spitsbergen and Greenland and are filled with Devonian Old Red Sandstones ( 5 in Fig. 2). Later a Permian faulting phase reactivated the Timan belt with the formation of a northwest-southeast horst-structure, parallel to the coastline (2 on Fig. 2).

The Tertiary opening of the Norwegian Sea [8] occurred along a median line of the Greenland-Norwegian Caledonides, up to Bear Island latitude. Barents Valley lines up with this direction and could be related to initial rifting.

North of Bear Island the pre-opening reconstruction indicates a shear motion between Greenland and Spitsbergen. This shear has created the narrow Tertiary orogenic belt of West Spitsbergen $[9,10]$.

\section{Previous work}

A seismic refraction survey was carried out in 1969 and 1970 by the Lamont-Doherty Geological Observatory [11]. Another seismic refraction survey was done by the University of Bergen [12] in September 1970 using a fixed shotpoint technique.

Both studies indicated that the Barents Sea was underlain by a sequence of layered sediments (probably of Mesozoic and Paleozoic age) and that a low-velocity Cenozoic wedge existed near the shelf edge.

Eldholm and Ewing [11] suggested that the western basement is irregular and corresponds to a continuation of the Caledonides while the eastern basement is smoother and is associated with the Proterozoic and early Paleozoic structural complex.

\section{Geophysical measurements}

A total of 45 sonobuoys were used in the Barents Sea. Bathymetry, seismic reflection and gravity were recorded along all profiles. Magnetics were only recorded along the east-west profile at $73^{\circ} 5 \mathrm{~N}$. Seismic source was flexotir with two guns operated simultaneously. Shooting frequency was 30 seconds. A 1400-m long six-traces streamer was used. Data were recorded digitally as well as on seismic cameras and paper monitors. A 40-cubic-inch airgun was shot every 2 seconds between flexotir shots and recorded on a short eel. A Graf-Askania GSS 2 sea gravimeter was used with no cross-coupling computer.

\section{Seismic reflection}

Seismic reflection records yield few usable data on the Barents shelf due to multiples and the presence of bedrock close to the surface. Only in certain circumstances have deep seismic reflections been observed. Profile $X X^{\prime}$ (located in Fig. 5) is shown in Fig. 3 in which two folds are clearly displayed at about $1 \mathrm{sec}$ two-way travel time. Other structures can be guessed along other profiles but the quality of the data is not sufficient to make good use of this information. 


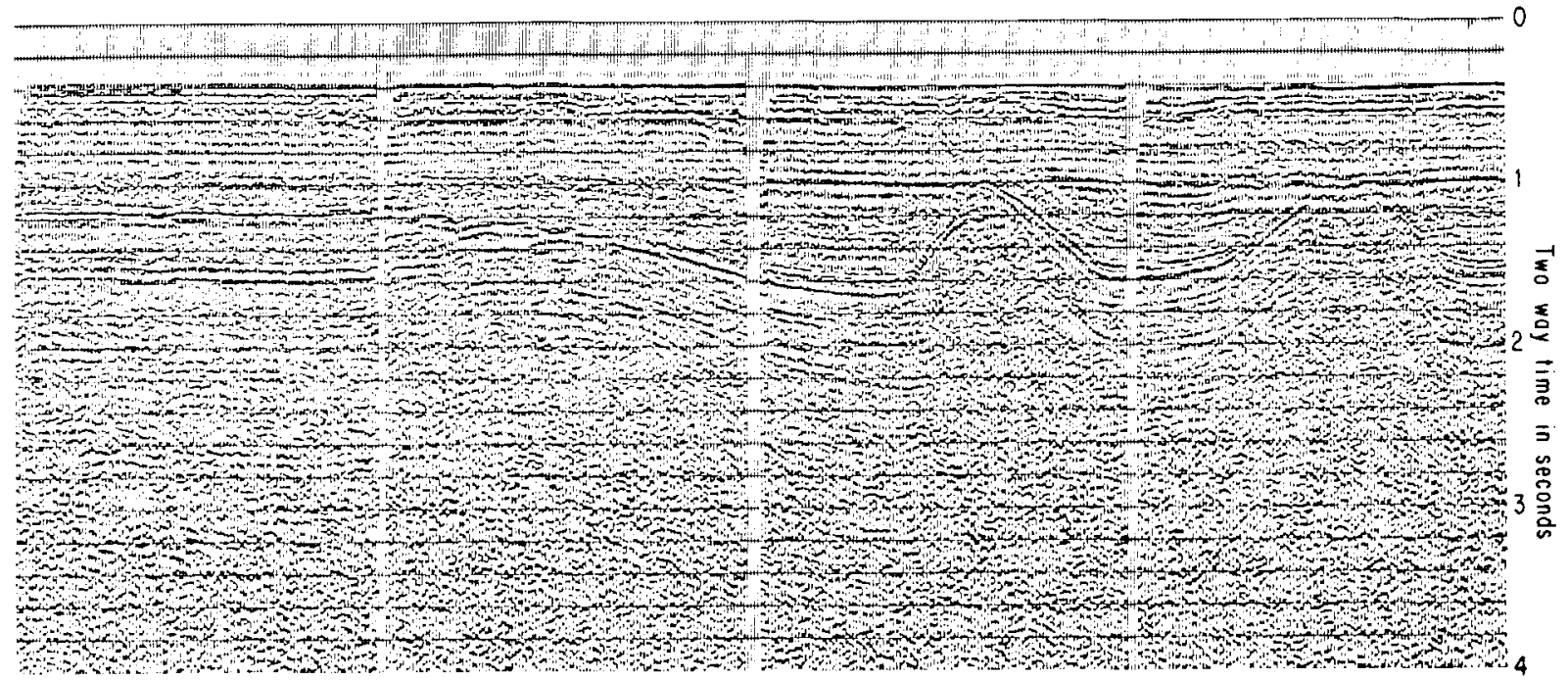

Fig. 3. Processed seismic reflection profile $X X^{\prime}$ (Fig. 5). Variable area record. Vertical scale is two-way travel time. Length of profiles is 20 nautical miles.

\section{Gravimetry}

A free-air anomaly gravimetric map (Fig. 4) has been compiled from Lamont Doherty Geological Observatory [11], French Hydrographic Service and present cruise data.

The main features of this map are the positive high parallel to the margin corresponding to the edge effect, and a series of southwest-northeast positive and negative trends across the southwestern Barents Sea. Over Spitsbergen Bank the gravity field appears to be smooth.

\section{Seismic refraction}

Sonobuoys profiles are indicated on Fig. 5, together with previous Lamont and Bergen refraction stations. The quality of the record is variable and the typical range is about 10 miles. Curved hodochrones were observed at 18 stations. Fig. 6 shows such a record. Similar observations were first made by Eldholm and Ewing [11] who used the WiechertHerglotz integral to find the corresponding velocitydepth function. In order to develop this method further a computer program was written to integrate in a single operation the case of a variable velocity layer followed by discrete velocity layers. The main lines of the program are as follows:

First, the curved and linear segments of the traveltime graph are digitized (Fig. 6A) and reduced to sea bottom. A third-order polynomial is then least-squares fitted to the data.

Application of the Wiechert-Herglotz integral [13] yields the depth and the velocity at every computation point (Fig. 6B). The theoretical intercept between the curved portion of the graph and the first linear segment is then computed and compared to the measured intercept. The curved portion is extrapolated until the two intercepts agree and the correct depth is attained. Subsequent linear segments can then be solved for depth and velocity.

In Fig. 5 the correlation for the continuous velocity-depth relationship layer is obtained by joining depths of equal velocity. In order to compare velocity laws, vertical velocity gradients have been plotted versus depth (Fig. 6C). These curves display a section with a linear slope which has been used to recompute the velocity function in order to reduce the influence of the extrapolated ends of the hodochrone. 


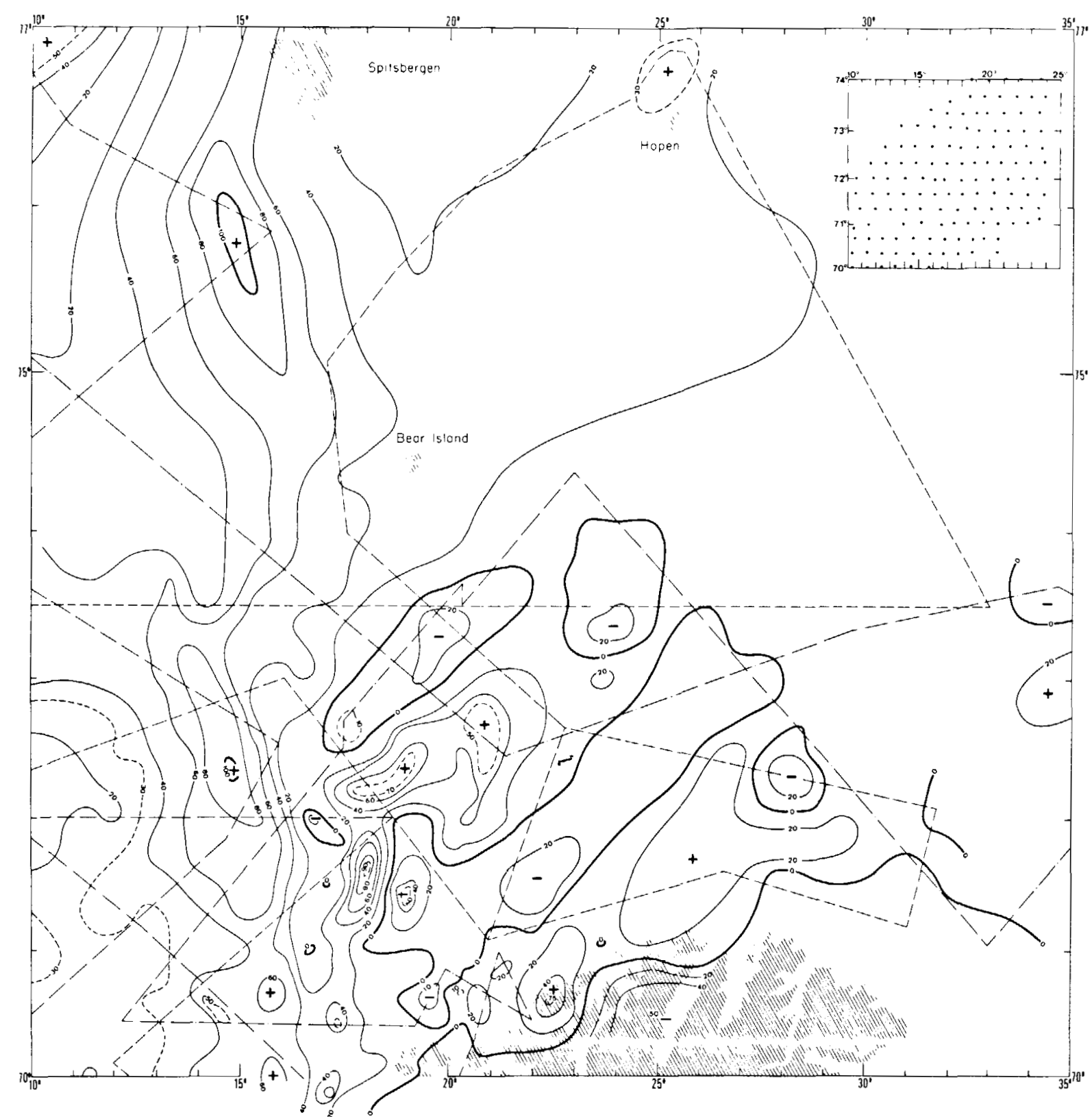

Fig. 4. Free-air anomaly gravity map. Contour interval is 10 mgals. Track lines of the ship data (Lamont and Cnexo) used is shown. In upper right corner grid of French Navy Hydrographic Service data is shown.

At the other stations, rectilinear refractors were observed and discrete velocities were obtained by fitting straight lines to the travel-time graphs. The results are combined in Table 1.

The histogram in Fig. 7 gives the distribution of seismic velocities for all discrete velocity layers. Several groups of velocities can be outlined.

\subsection{Layers of $2.2 \mathrm{~km} / \mathrm{sec}$ or less}

The lowest velocity layers $(1.98-2.20 \mathrm{~km} / \mathrm{sec})$ are observed west of the shelf edge. At station 41 and $42,2.5 \mathrm{~km}$ of sediments with velocities below $3 \mathrm{~km} /$ $\mathrm{sec}$ are found.

East of the shelf edge, no layer with a velocity smaller than $2.2 \mathrm{~km} / \mathrm{sec}$ was detected on sonobuoy 


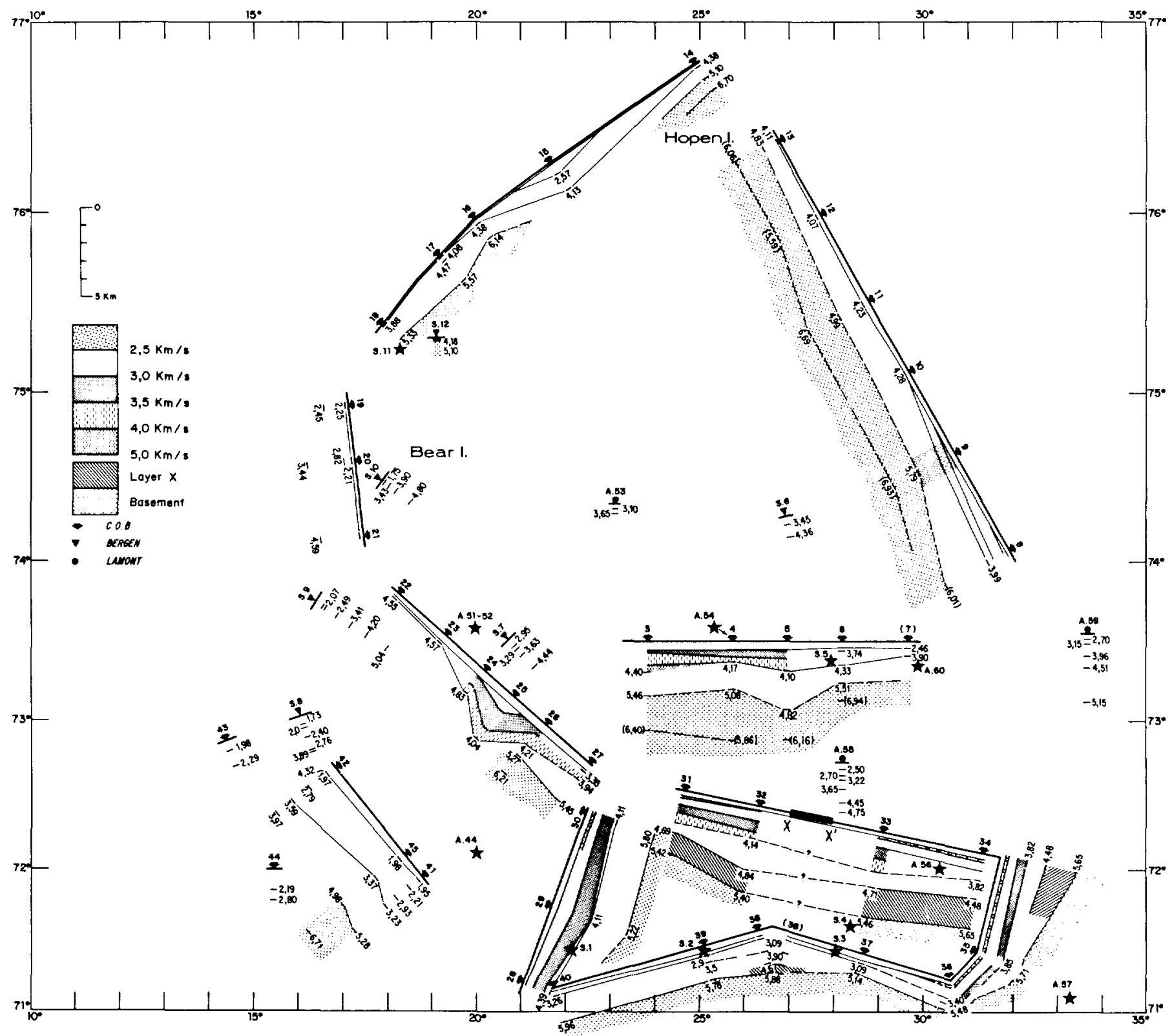

Fig. 5. Refraction profiles position and sections correlated along ship track. Velocity legend refers to variable velocity and not to discrete layers except for layer $X$ and basement. Data from Eldholm and Ewing [11] and Sundvor and Sellevoll [12] have been included to complete coverage. Star is used when station results have not been used in the figure. Position of reflection profile $X X^{\prime}$ is shown between stations 32 and 33. 
V. RENARD AND J. MALOD

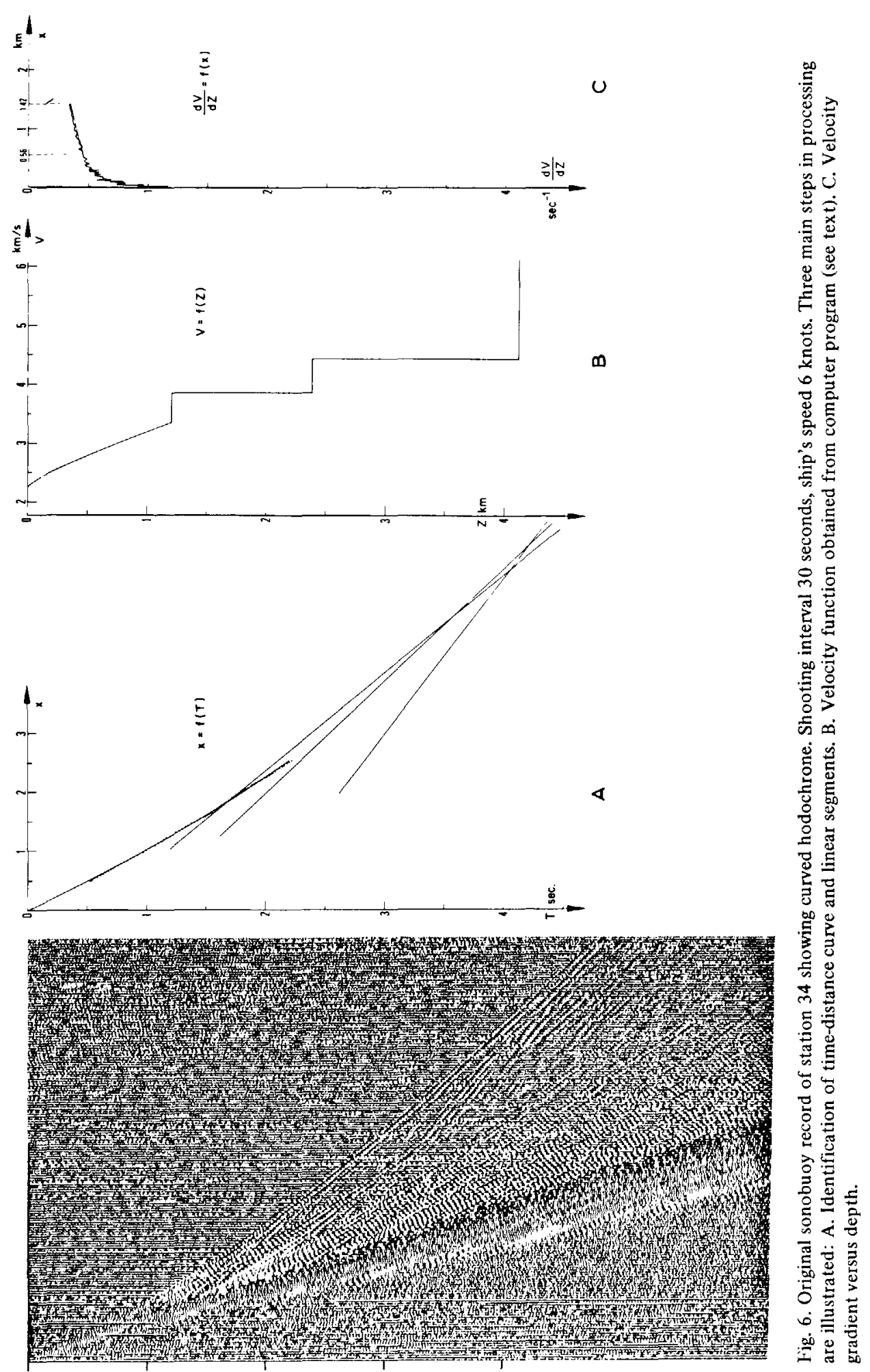




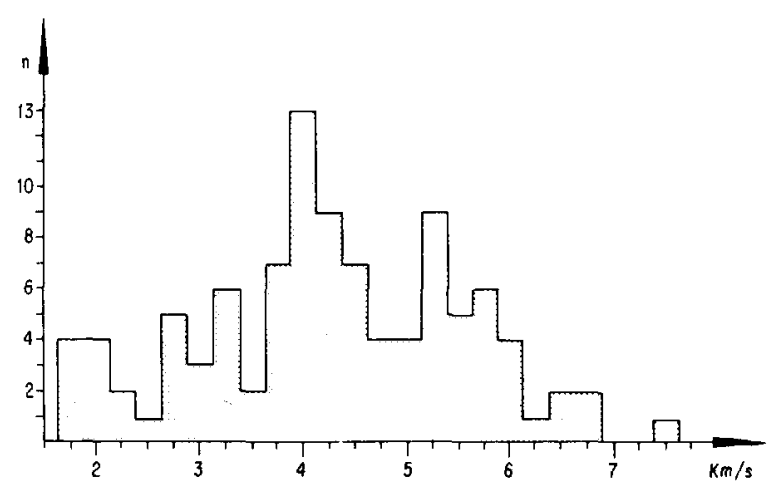

Fig. 7. Histogram of discrete velocity refracted waves only, plotted with $0.25 \mathrm{~km} / \mathrm{sec}$ step for all stations.

records. Airgun records indicate, however, the presence of a thin transparent (less than $0.1 \mathrm{sec}$ ) layer probably with a very low seismic velocity.

\subsection{Layers of $2.3-3.8 \mathrm{~km} / \mathrm{sec}$}

\subsubsection{Zone with velocity function}

There are two distinct zones with velocity function. A first one with surface velocities of the order of 2.6 $\mathrm{km} / \mathrm{sec}$ (buoys 28-36), and a second one with surface velocities of the order of $3 \mathrm{~km} / \mathrm{sec}$ (buoys $3-5,8,9$, 26 ). For both zones the velocity function is similar and the maximum attained velocity is about 3.8 $\mathrm{km} / \mathrm{sec}$. Eldholm and Ewing [11] found in our first zone three seismic velocities at A55 (2.5, 2.7, 3.22 $\mathrm{km} / \mathrm{sec}), \operatorname{A5} 6(2.48,2.75,3.15 \mathrm{~km} / \mathrm{sec}), \operatorname{A} 57(2.2$, $2.5,2.8 \mathrm{~km} / \mathrm{sec}$ ) and so did Sundvor and Sellevoll [12] at $\mathrm{S} 1(2.31,2.60,3.11 \mathrm{~km} / \mathrm{sec})$. These velocities are a little apart and could correspond at the limit to the observed continuous velocity function.

\subsubsection{Zone with discrete horizons}

Outside the two previous zones, velocity of the order of $3 \mathrm{~km} / \mathrm{sec}$ is found mostly on the northern edge of Norway (buoys 37-40) and Bergen S5 and S7. This velocity is also present around Hopen Island as computed from the difference of travel time between trace 1 and trace 6 of the seismic array. The corresponding layer is probably too thin to be detected by the seismic refraction method.

West of the Bear Island-Norway parallel units with equivalent $3.0 \mathrm{~km} / \mathrm{sec}$ velocity are found up to the 500-m isobath; stations $41,42,45,44$, S8, S9,
A44, A43, A50. Buoy 15, shot near Storfjord Valley also displays low velocity $(2.58 \mathrm{~km} / \mathrm{sec})$.

\subsection{Intermediate-velocity layers}

Below the previous layer an horizon with seismic velocities ranging from 3.8 to $4.4 \mathrm{~km} / \mathrm{sec}$ is found at stations 28-35, 42, and 2-5. Eldholm and Ewing [11] found a similar velocity at stations A52, A54 and Sundvor and Sellevoll [12] at stations S1, S4, S12. The histogram (Fig. 7) shows that this group of velocity is centered around $4.1 \mathrm{~km} / \mathrm{sec}$. Exceptions are stations 39 and neighbouring S2, 37 and neighbouring $\mathrm{S} 3$, all close to the Norwegian coast.

In a zone outlined by stations 6, 31-34, 38, A55, A56, A57 and A60 the solution best fitted to the data is to consider two layers, one with seismic velocities $(3.7-4.1)$ and another one $(4.4-4.8 \mathrm{~km} / \mathrm{sec})$. This solution is illustrated on Fig. 5 where the lower layer is marked layer $X$.

At buoys 22-24, A51 and A57 velocities fall in a range centered around $4.6 \mathrm{~km} / \mathrm{sec}$. All these stations lie just south of Bear Island and reflect the presence of a ridge extending southward from that island.

\subsection{High-velocity layers}

High seismic velocities are found at most stations and are centered around $5.4 \mathrm{~km} / \mathrm{sec}$ as shown on the histogram (Fig. 7).

Higher velocities are measured (buoys $3,6,11,13$, $14,16,26)$ in areas where the basement is shallower. These velocities are poorly determined due to the limited range of the sonobuoys.

\section{Interpretation}

\subsection{High-velocity layers}

In Norway, the basement layer has seismic velocities of $6.0 \mathrm{~km} / \mathrm{sec}$ for the Precambrian granite, 6.2 and $6.33 \mathrm{~km} / \mathrm{sec}$ for the Caledonian Mountain Range and highly metamorphosed Cambro-Silurian section [14].

Demenitskaya et al. [15] indicated that the surface of the consolidated crust is well outlined (boundary with $V=6.0-6.1 \mathrm{~km} / \mathrm{sec}$ ) in the Barents Sea and corresponds with the surface of the granitic layer outcropping on the Baltic shield.

The scatter of our data is large. Some velocities fall in the $6-\mathrm{km} / \mathrm{sec}$ range but it is impossible to dissociate 


\section{TABLE 1}

Position, depth and results of refraction stations used in this study

\begin{tabular}{|c|c|c|c|c|c|c|c|c|c|c|c|c|}
\hline \multirow[t]{2}{*}{ Station } & \multicolumn{3}{|l|}{ Position } & \multicolumn{3}{|c|}{ Variable velocity layer } & \multicolumn{6}{|c|}{ Discrete velocity layer } \\
\hline & lat..N & long. E & depth & $Z_{\max }$ & $V=f(Z)$ & $V_{\max }$ & $\mathrm{V} 1 / \mathrm{HI}$ & $\mathrm{V} 2 / \mathrm{H} 2$ & $\mathrm{~V} 3 / \mathrm{H} 3$ & $\mathrm{~V} 4 / \mathrm{H} 4$ & V5/H5 & $\mathrm{V} 6 / \mathrm{H} 6$ \\
\hline 2 & $73^{\circ} 30$ & $19^{\circ} 30$ & 0.45 & & & & $\left\{\begin{array}{l}1.47 \\
0.45\end{array}\right.$ & 4.26 & & & & \\
\hline * 3 & $73^{\circ} 39.6$ & $23^{\circ} 52$ & 0.44 & 1.28 & $3.3+0.75 Z-0.02 Z^{2}$ & 4.28 & $\left\{\begin{array}{l}4.40 \\
1.35\end{array}\right.$ & $\left\{\begin{array}{l}5.46 \\
1.95\end{array}\right.$ & 6.40 & & & \\
\hline$* 4$ & $73^{\circ} 38.8$ & $25^{\circ} 47.4$ & 0.44 & 0.70 & $3.1+0.98 Z$ & 3.76 & $\left\{\begin{array}{l}4.17 \\
1.59\end{array}\right.$ & $\left\{\begin{array}{l}5.08 \\
2.91\end{array}\right.$ & 5.86 & & & \\
\hline * 5 & $73^{\circ} 29.4$ & $27^{\circ} 00$ & 0.42 & 1.20 & $3+1.06 Z-0.1 Z^{2}$ & 4.10 & 4.08 & & & & & \\
\hline 6 & $73^{\circ} 30$ & $28^{\circ} 11.5$ & 0.38 & & & & $\left\{\begin{array}{l}1.47 \\
0.55\end{array}\right.$ & $\left\{\begin{array}{l}3.74 \\
0.79\end{array}\right.$ & $\left\{\begin{array}{l}4.33 \\
1.03\end{array}\right.$ & $\left\{\begin{array}{l}5.51 \\
0.99\end{array}\right.$ & 6.94 & \\
\hline 7 & $73^{\circ} 28$ & $29^{\circ} 40$ & 0.39 & & & & $\left\{\begin{array}{l}1.47 \\
0.68\end{array}\right.$ & 4.17 & & & & \\
\hline * 8 & $74^{\circ} 08.7$ & $31^{\circ} 46.7$ & 0.26 & 1.19 & $2.9+0.72 Z$ & 3.97 & $\left\{\begin{array}{l}3.99 \\
1.19\end{array}\right.$ & 6.01 & & & & \\
\hline * 9 & $74^{\circ} 38.7$ & $30^{\circ} 41.2$ & 0.32 & 2.09 & $3.4+0.58 Z$ & 4.66 & $\left\{\begin{array}{l}5.79 \\
1.58\end{array}\right.$ & 6.93 & & & & \\
\hline 10 & $74^{\circ} 38.7$ & $29^{\circ} 38.7$ & 0.38 & & & & $\left\{\begin{array}{l}1.47 \\
0.27\end{array}\right.$ & 4.28 & & & & \\
\hline 11 & $75^{\circ} 31.1$ & $28^{\circ} 42.3$ & 0.33 & & & & $\left\{\begin{array}{l}1.47 \\
0.41\end{array}\right.$ & $\left\{\begin{array}{l}4.23 \\
1.55\end{array}\right.$ & $\left\{\begin{array}{l}4.99 \\
1.88\end{array}\right.$ & $(6.69)$ & & \\
\hline 12 & $75^{\circ} 58.8$ & $27^{\circ} 31.8$ & 0.24 & & & & $\left\{\begin{array}{l}1.47 \\
0.28\end{array}\right.$ & $\left\{\begin{array}{l}4.07 \\
2.46\end{array}\right.$ & 5.59 & & & \\
\hline 13 & $76^{\circ} 22.9$ & $26^{\circ} 41.5$ & 0.135 & & & & $\left\{\begin{array}{l}1.47 \\
0.13\end{array}\right.$ & $\left\{\begin{array}{l}4.11 \\
0.85\end{array}\right.$ & $\left\{\begin{array}{l}4.83 \\
1.80\end{array}\right.$ & 6.06 & & \\
\hline 14 & $76^{\circ} 47.7$ & $24^{\circ} 51.0$ & 0.05 & & & & $\left\{\begin{array}{l}1.47 \\
0.08\end{array}\right.$ & $\left\{\begin{array}{l}4.38 \\
0.81\end{array}\right.$ & $\left\{\begin{array}{l}5.10 \\
0.88\end{array}\right.$ & 6.70 & & \\
\hline 15 & $76^{\circ} 16.5$ & $21^{\circ} 37$ & 0.18 & & & & $\left\{\begin{array}{l}1.47 \\
0.61\end{array}\right.$ & $\left\{\begin{array}{l}2.58 \\
1.15\end{array}\right.$ & 4.13 & & & \\
\hline 16 & $75^{\circ} 56.8$ & $19^{\circ} 58$ & 0.10 & & & & $\left\{\begin{array}{l}1.47 \\
0.25\end{array}\right.$ & $\left\{\begin{array}{l}4.38 \\
0.99\end{array}\right.$ & 6.14 & & & \\
\hline 17 & $75^{\circ} 40$ & $19^{\circ} 10$ & 0.07 & & & & $\left\{\begin{array}{l}1.47 \\
0.05\end{array}\right.$ & $\left\{\begin{array}{l}4.08 \\
0.30\end{array}\right.$ & $\left\{\begin{array}{l}4.47 \\
1.57\end{array}\right.$ & 5.57 & & \\
\hline 18 & $75^{\circ} 23.3$ & $17^{\circ} 52$ & 0.11 & & & & $\left\{\begin{array}{l}1.47 \\
0.09\end{array}\right.$ & $\left\{\begin{array}{l}3.89 \\
1.26\end{array}\right.$ & 5.33 & & & \\
\hline 19 & $74^{\circ} 54.9$ & $17^{\circ} 04.7$ & 0.18 & & & & $\left\{\begin{array}{l}1.47 \\
0.12\end{array}\right.$ & $\left\{\begin{array}{l}2.25 \\
1.22\end{array}\right.$ & 2.45 & & & \\
\hline 20 & $74^{\circ} 35.6$ & $17^{\circ} 11.0$ & 0.15 & & & & $\left\{\begin{array}{l}1.47 \\
0.12\end{array}\right.$ & $\left\{\begin{array}{l}2.21 \\
0.45\end{array}\right.$ & $\left\{\begin{array}{l}2.82 \\
2.10\end{array}\right.$ & 3.44 & & \\
\hline$* 21$ & $74^{\circ} 09.0$ & $17^{\circ} 27.5$ & 0.18 & 2.22 & $2.12+0.95 Z$ & 4.22 & 4.59 & & & & & \\
\hline
\end{tabular}




\begin{tabular}{|c|c|c|c|c|c|c|c|c|c|c|c|c|}
\hline 22 & $73^{\circ} 47.4$ & $18^{\circ} 13.0$ & 0.25 & & & & $\left\{\begin{array}{l}1.47 \\
0.31\end{array}\right.$ & 4.55 & & & & \\
\hline 23 & $73^{\circ} 32.7$ & $19^{\circ} 16.6$ & 0.42 & & & & $\left\{\begin{array}{l}1.47 \\
0.59\end{array}\right.$ & 4.57 & & & & \\
\hline$* 24$ & $73^{\circ} 19.2$ & $20^{\circ} 14.7$ & 0.47 & 1.69 & $2.6+0.92 Z-0.1 Z^{2}$ & 3.83 & 4.83 & & & & & \\
\hline *25 & $73^{\circ} 08.0$ & $20^{\circ} 52$ & 0.46 & 2.74 & $2.6+0.5 Z-0.05 Z^{2}$ & 3.70 & $\left\{\begin{array}{l}4.04 \\
2.74\end{array}\right.$ & & & & & \\
\hline *26 & $72^{\circ} 58.2$ & $21^{\circ} 31.2$ & 0.45 & 1.09 & $3.15+1.2 Z-0.25 Z^{2}$ & 4.16 & $\left\{\begin{array}{l}4.21 \\
0.78\end{array}\right.$ & $\left\{\begin{array}{l}5.27 \\
1.31\end{array}\right.$ & 6.21 & & & \\
\hline 27 & $72^{\circ} 42.1$ & $22^{\circ} 39.5$ & 0.42 & & & & $\left\{\begin{array}{l}1.47 \\
0.57\end{array}\right.$ & $\left\{\begin{array}{l}3.35 \\
0.56\end{array}\right.$ & $\left\{\begin{array}{l}3.94 \\
1.65\end{array}\right.$ & 5.45 & & \\
\hline *28 & $71^{\circ} 12.1$ & $22^{\circ} 39.5$ & 0.19 & 1.46 & $2.6+0.89 Z-0.08 Z^{2}$ & 3.76 & 4.39 & & & & & \\
\hline *29 & $71^{\circ} 43.1$ & $21^{\circ} 36.5$ & 0.32 & 2.05 & $2.6+0.6 Z-0.13 Z^{2}$ & 3.46 & $\left\{\begin{array}{l}4.11 \\
2.21\end{array}\right.$ & 5.22 & & & & \\
\hline *30 & $72^{\circ} 22.1$ & $22^{\circ} 31.3$ & 0.32 & 1.43 & $2.5+1.06 Z-0.13 Z^{2}$ & 3.64 & $\left\{\begin{array}{l}4.11 \\
2.34\end{array}\right.$ & 5.80 & & & & \\
\hline *31 & $72^{\circ} 33.8$ & $24^{\circ} 40$ & 0.30 & 2.17 & $2.5+1.13 Z-0.1 z^{2}$ & 4.40 & $\left\{\begin{array}{l}4.69 \\
1.27\end{array}\right.$ & 5.42 & & & & \\
\hline *32 & $72^{\circ} 26.6$ & $26^{\circ} 18$ & 0.26 & 1.62 & $2.6+0.76 Z-0.05 Z^{2}$ & 3.72 & $\left\{\begin{array}{l}4.14 \\
1.82\end{array}\right.$ & $\left\{\begin{array}{l}4.84 \\
1.30\end{array}\right.$ & 5.40 & & & \\
\hline *33 & $72^{\circ} 16.8$ & $29^{\circ} 05.4$ & 0.26 & 2.96 & $2.5+0.90 Z-0.08 Z^{2}$ & 4.46 & $\left\{\begin{array}{l}4.71 \\
1.74\end{array}\right.$ & 5.46 & & & & \\
\hline$* 34$ & $72^{\circ} 06.9$ & $31^{\circ} 20$ & 0.31 & 1.21 & $2.4+1.26 Z-0.29 Z^{2}$ & 3.40 & $\left\{\begin{array}{l}3.82 \\
1.06\end{array}\right.$ & $\left\{\begin{array}{l}4.48 \\
1.78\end{array}\right.$ & 5.65 & & & \\
\hline *35 & $71^{\circ} 23.8$ & $31^{\circ} 15.5$ & 0.27 & 1.27 & $2.4+0.99 Z-0.23 Z^{2}$ & 3.18 & $\left\{\begin{array}{l}3.85 \\
1.09\end{array}\right.$ & 5.71 & & & & \\
\hline$* 36$ & $71^{\circ} 14.3$ & $30^{\circ} 35$ & 0.29 & 0.81 & $2.4+0.79 Z$ & 3.06 & $\left\{\begin{array}{l}3.38 \\
0.64\end{array}\right.$ & 5.40 & & & & \\
\hline 37 & $71^{\circ} 24.0$ & $28^{\circ} 38.7$ & 0.38 & & & & $\left\{\begin{array}{l}1.47 \\
0.55\end{array}\right.$ & $\left\{\begin{array}{l}3.09 \\
0.65\end{array}\right.$ & 5.14 & & & \\
\hline 38 & $71^{\circ} 34.2$ & $26^{\circ} 16.4$ & 0.34 & & & & $\left\{\begin{array}{l}1.47 \\
0.54\end{array}\right.$ & $\left\{\begin{array}{l}3.09 \\
0.77\end{array}\right.$ & $\left\{\begin{array}{l}3.90 \\
0.71\end{array}\right.$ & $\left\{\begin{array}{l}4.67 \\
0.58\end{array}\right.$ & 5.88 & \\
\hline 39 & $71^{\circ} 27.4$ & $25^{\circ} 06.5$ & 0.39 & & & & $\left\{\begin{array}{l}1.47 \\
0.57\end{array}\right.$ & $\left\{\begin{array}{l}2.90 \\
0.37\end{array}\right.$ & $\left\{\begin{array}{l}3.50 \\
1.06\end{array}\right.$ & 5.78 & & \\
\hline 40 & $71^{\circ} 09.1$ & $21^{\circ} 43.9$ & 0.19 & & & & $\left\{\begin{array}{l}1.47 \\
0.48\end{array}\right.$ & $\left\{\begin{array}{l}3.26 \\
1.52\end{array}\right.$ & 5.96 & & & \\
\hline 41 & $71^{\circ} 57.9$ & $18^{\circ} 37.8$ & 0.32 & & & & $\left\{\begin{array}{l}1.47 \\
0.26\end{array}\right.$ & $\left\{\begin{array}{l}1.91 \\
0.68\end{array}\right.$ & $\left\{\begin{array}{l}2.21 \\
0.95\end{array}\right.$ & $\left\{\begin{array}{l}2.93 \\
0.79\end{array}\right.$ & $\left\{\begin{array}{l}3.23 \\
2.27\end{array}\right.$ & 5.28 \\
\hline 42 & $72^{\circ} 41.2$ & $16^{\circ} 50$ & 0.39 & & & & $\left\{\begin{array}{l}1.47 \\
0.53\end{array}\right.$ & $\left\{\begin{array}{l}1.97 \\
1.33\end{array}\right.$ & $\left\{\begin{array}{l}2.79 \\
1.23\end{array}\right.$ & $\left\{\begin{array}{l}3.59 \\
1.13\end{array}\right.$ & 3.98 & \\
\hline 43 & $72^{\circ} 51$ & $14^{\circ} 24.2$ & 0.92 & & & & $\left\{\begin{array}{l}1.47 \\
0.62\end{array}\right.$ & $\left\{\begin{array}{l}1.98 \\
0.91\end{array}\right.$ & 2.29 & & & \\
\hline 44 & $71^{\circ} 59.5$ & $15^{\circ} 27.2$ & 0.75 & & & & $\left\{\begin{array}{l}1.47 \\
1.15\end{array}\right.$ & $\left\{\begin{array}{l}2.19 \\
0.63\end{array}\right.$ & 2.80 & & & \\
\hline 45 & $71^{\circ} 59.6$ & $18^{\circ} 06.4$ & 0.30 & & & & $\left\{\begin{array}{l}1.47 \\
0.31\end{array}\right.$ & $\left\{\begin{array}{l}1.98 \\
1.70\end{array}\right.$ & $\left\{\begin{array}{l}3.37 \\
2.46\end{array}\right.$ & 4.58 & & \\
\hline
\end{tabular}

* Star in front of station number indicates the existence of variable velocity layers over deeper discrete velocity ones. For variable velocity layers maximum computed velocity and depth are given as well as velocity function $V=f(Z)$. 


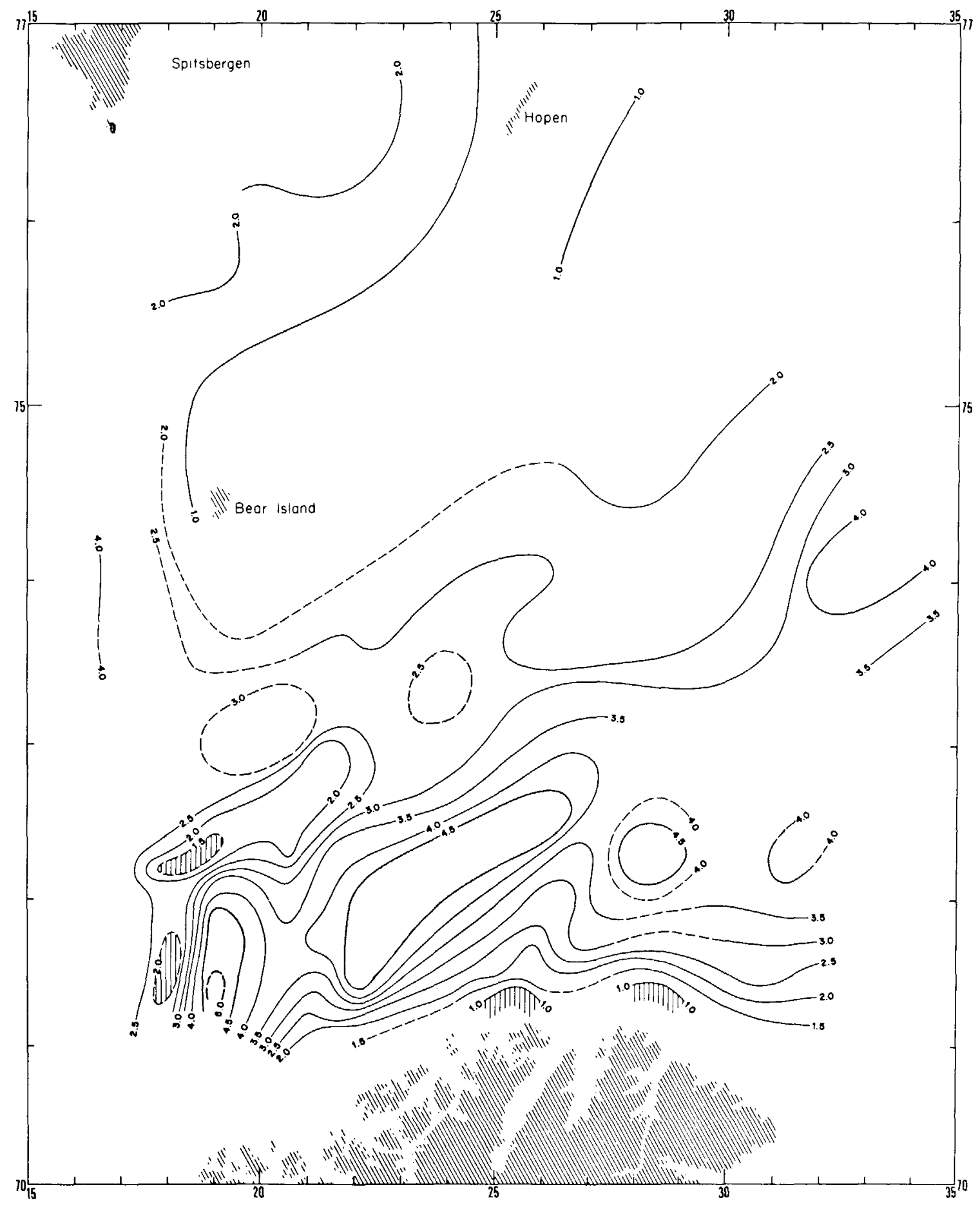

Fig. 8. Isobath map of $5.4-\mathrm{km} / \mathrm{sec}$ (mean velocity) "basement" layer. Contour interval is $0.5 \mathrm{~km} / \mathrm{sec}$. 


\section{STRUCTURE OF THE BARENTS SEA}

Precambrian rocks from metamorphosed Paleozoic rocks of the Caledonian complex. High values of seismic velocities (up to $6.9 \mathrm{~km} / \mathrm{sec}$ ) are probably due to the presence of basement structures.

\subsection{The $5.4 \mathrm{~km} / \mathrm{sec}$ unit}

This unit has less variable seismic velocities and has been mapped in Fig. 8. It does correspond probably to a basement [16], but of rather complex nature. To the north, this layer becomes progressively shallower towards Spitsbergen Island and could correspond to the metamorphosed Proterozoic and early Paleozoic formation of Heckla Hoeck. This basement seems continuous over Spitsbergen Bank.

To the south, this basement deepens and its relief becomes more accentuated. No visible change in seismic velocity can be detected from Spitsbergen Bank to the southern region. However, the rapid increase in basement depth suggests the presence of a structure along the southeastern limit of Spitsbergen Bank.

Basement morphology corresponds to a succession of highs and lows. Close correspondence between basement depressions and gravity anomalies indicate that most of the gravity effect is due to basement relief, and that sediments fill the depressions. The northeast-southwest trend is dominant. From previous geological data and from the direction of these structures, a late Caledonian age can be assessed. Hercynian trends of the Timan chain do not appear clearly.

The overall presence of this basement and its limited range of seismic velocity suggest that rather stable conditions have prevailed throughout the area. Fortey and Bruton [17] suggest that a carbonate platform existed during Cambrian and Ordovician times. The 5.4- $\mathrm{km} / \mathrm{sec}$ basement could correspond to this episode and represent the Cambrian to Silurian sequence. Westward the spread in seismic velocity increases and reflects probably an increased degree of folding and metamorphism.

\subsection{Sedimentary layers}

The $4.1-\mathrm{km} / \mathrm{sec}$ layer is very well defined and continuous throughout the entire area. At Hopen Island, where this layer is close to the surface, Triassic beds outcrop under Jurassic and Cretaceous tabular layers [18]. These Triassic beds could correspond to the thin layer of $3.0 \mathrm{~km} / \mathrm{sec}$ determined from the seismic array, while the $4.1 \mathrm{~km} / \mathrm{sec}$ would correspond and be compatible with seismic velocities of Permian [17-20] limestone known in Spitsbergen. This upper layer thickness varies between 1.5 and $2 \mathrm{~km}$ in the south Barents Sea to less than $1 \mathrm{~km}$ in the vicinity of Hopen. A Carboniferous to Permian age would agree with seismic velocities, uniformity and thickness of this layer.

Layer $X$ is either a thicker section of Carbo-Permian units or an older unit. If it is Carbo-Permian with higher velocities due to compaction or facies change, it would indicate that the southeast region subsided faster than the surrounding area and formed a closed basin.

If it is an older unit, it could be Devonian in age. Up to $8 \mathrm{~km}$ of Devonian are found in Spitsbergen while very little is found on Bear Island. This and the absence of layer $X$ on Spitsbergen Bank suggests that this bank was an elevated area during or shortly after the Devonian before the deposition of the uniform upper layer.

The depth of layer $X$ corresponds to the depth of the folded layer seen in seismic record $X X^{\prime}$ (Fig. 3) between station 32 and 33 . This layer may represent the roof of a salt layer as suggested by the succession of anticlines bordered by a depressed layer on either side, by the deformation reaching the upper most layers, and by the seismic velocity. The salt layer bottom reflector is, however, not visible.

The zone with velocity function is restricted to an area lying southeast of the Barents Valley. The continuous increase of velocity indicates either increase of composition, depth and age [19], lithological variations or all these factors together. Depth is, however, the most important factor since the others are indirectly function of it. Progressive subsidence of an originally extensive basin and restriction of the sedimentation to the central area could explain the creation of the zone with greatest thicknesses in its center. The thickness of the unit points to a period of great stability after deposition of the $4.1-\mathrm{km} / \mathrm{sec}$ formation. The sediments of this basin are therefore of Mesozoic and Cenozoic age. To the north of this zone, greater surface velocity $(3 \mathrm{~km} / \mathrm{sec})$ may indicate erosion of the upper part of the unit, due to the uplift of the near Spitsbergen Bank. To the south, near the Norwegian margin, the absence of velocity function indicates that 
the stations lie probably outside the basin. Spjeldnaes [21] has reported the existence of Mesozoic bedrock exposed on the bottom of the Barents Sea. If his sample is really in place, it would further support the existence of surface velocity in the $2.5-3-\mathrm{km} / \mathrm{sec}$ range and the Mesozoic age of most Barents Sea floor.

On the continental margin west of Bear Island longitude, the succession of very low velocity $(2-2.2 \mathrm{~km} /$ sec) and intermediary velocity $(3.3 \mathrm{~km} / \mathrm{sec})$ can be correlated with prograded units. This Tertiary progradation [22] is quite clear from the overlap in the preopening fit of this part of the margin (Fig. 2) and from seismic reflection data. Finally, the low velocity found at station 15 near Storfjord and station 25 in the Barents Valley corresponds to a Tertiary filling of marginal depressions.

\section{Conclusion}

Seismic refraction with sonobuoys has helped to outline the structure of the Barents Sea basin. Although velocity scatter is high, four main units are outlined: (1) a high-velocity Precambrian crystalline basement with velocities around $6.0 \mathrm{~km} / \mathrm{sec}$; (2) a more or less metamorphosed Paleozoic basement with velocities around $5.4 \mathrm{~km} / \mathrm{sec}$; (3) an intermediate-velocity layer $(4.1 \mathrm{~km} / \mathrm{sec})$ of Carboniferous to Permian age, with possibly an older layer or a salt layer limited to the central area; (4) a variable velocity layer $(2.4-4.0 \mathrm{~km} /$ $\mathrm{sec}$ ) of Mesozoic and Cenozoic age and limited to the south of the Barents Sea.

Very low-velocity $(2.2 \mathrm{~km} / \mathrm{sec})$ layers are detected close to the shelf edge where prograding units are present.

The impossibility of differentiation of basement nature from seismic velocity does not permit to bring any new information on the extension of the fold belts into the Barents Sea.

However, the Caledonian axis Spitsbergen-Bear Island appears to continue somewhat to the south. Also the dominant northeast-southwest trend of the basement and gravity anomaly maps seems to correspond to the Caledonides chain of Norway.

\section{Acknowledgments}

The authors thank the officers and crew of the
R.V. "Jean Charcot" for their help during the cruise. They are grateful to Dr. X. Le Pichon, J. Goslin and J.C. Sibuet for helpful discussions and for their critical review of the manuscript.

\section{References}

$1 \mathrm{~J}$. Eggvin, Bathymetric Chart of the Norwegian Sea and Adjacent Areas (Fiskeridirektoratets Havforsknings Institutt, Bergen, 1963).

2 L. Lliboutry, Traité de Glaciologie (Masson, Paris, 1964-1965) 2 vols.

3 V. Schytt, G. Hoppe, W. Blake, Jr. and M.G. Grosswald, The extent of the Würm glaciation in the European Arctic, Meddel. Naturgeogr. Inst. Stockholm Univ., N20 (1968) 207.

$4 \mathrm{G}$. Hoppe, The Würm ice sheets of Northern and Arctic Europe, Acta Geogr. Lodziensia, no. 24 (1970) 205.

5 V.N. Sokolov, A.A. Krasiltshikov and J.J. Livshitz, The main features of the tectonic structure of Spitsbergen, Geol. Mag. G.B. 105 (1968) 95.

$6 \mathrm{H}$. Frebold, Geologie des Barentsschelfes, Abh. deutsch. Akad. Wiss. Verl. 5 (1951) 150 pp.

7 R.A. Gayer and J.D. Roberts, Stratigraphic review of the Finmark Caledonides, with possible tectonic implications, Proc. Geol. Assoc. 84 (1973) 405.

8 O.E. Avery, G.D. Burton, and J.R. Heirtzler, An aeromagnetic survey of the Norwegian Sea, J. Geophys. Res. 73 (1968) 4583.

9 W.B. Harland, Contribution of Spitzbergen to understanding of tectonic evolution of North Atlantic region, Am. Assoc. Pet. Geol. Mem. 12 (1969) 817.

10 J.D. Lowell, Spitsbergen Tertiary orogenic belt and the Spitsbergen fracture zone, Geol. Soc. Am. Bull. 83 (1972) 3091.

$11 \mathrm{O}$. Eldholm and J. Ewing, Marine geophysical survey in the southwestern Barents Sea, J. Geophys. Res. 76 (1971) 3832.

12 E. Sundvor and M.A. Sellevoll, Seismiske unders $\phi$ kelser av den Norske kontinentalsokkel-Lofoten, Bjornoya $\left(68^{\circ}-75^{\circ} \mathrm{N}\right)$, Univ. Bergen. Teknisk R. no. 5 (1971).

13 L.B. Slichter, Interpretation of seismic travel-time curves in horizontal structures, Physics 3 (1932) 273-295.

14 M.A. Sellevoll and R.E. Warrick, A refraction study of the crustal structure in southern Norway, Bull. Seismol. Soc. Am. 61 (1971) 457.

15 R.M. Demenitskaya, A.M. Karasik, Y.G. Kiselev, I.V. Litvinenko and S.A. Ushakov, The transition between the Eurasian continent and the Arctic ocean, Canad. J. Earth Sci. 5 (1968) 1125.

16 E. Sundvor, Seismic refraction measurements on the Norwegian continental shelf between Andöya and Fuglöybanken, Mar. Geophys. Res. 1 (1971) 303.

17 R.A. Fortey and D.L. Bruton, Cambrian-Ordovician rocks adjacent to Hinlopenstretet, north NY Friesland, Spitsbergen, Geol. Soc. Am. Bull. 84 (1973) 2227. 


\section{STRUCTURE OF THE BARENTS SEA}

18 B. Flood, J. Nagy and T.S. Winsnes, The Triassic succession of Barentsöya, Edgeöya and Hopen (Svalbard), Norsk Polarinst. Medd. Norge 100 (1971) 20 pp.

19 L.Y. Faust, Seismic velocity as a function of depth and geologic time, Geophysics XVI (1951) 192

20 S.M. Wyrobek, Well velocity determinations in the English

Trias, Permian and Carboniferous, Geophys. Prosp. 7

(1958) 218.
21 N. Spjeldnaes, Mesozoic (?) bedrock exposed on the bottom of the Barents Sea, Mar. Geol. 11 (1971) M45.

$22 \mathrm{~J}$. Malod and J. Mascle, Structures géologiques de la marge continentale à l'ouest du Spitsberg, Mar. Geophys. Res. 2 (1974) in press. 